\title{
Selected Chemical Properties of Soybean Rhizosphere Soil as Influenced by Cropping Systems, Rhizobium Inoculation, and the Supply of Phosphorus and Potassium after Two Consecutive Cropping Seasons
}

\author{
Daniel Nyoki $\mathbb{i D}^{1,2}$ and Patrick A. Ndakidemi ${ }^{1,2}$ \\ ${ }^{1}$ School of Life Science and Bio-Engineering, The Nelson Mandela African Institution of Science and Technology, \\ P.O. Box 447, Arusha, Tanzania \\ ${ }^{2}$ Centre for Research, Agricultural Advancement, Teaching Excellence and Sustainability (CREATES) in Food and Nutrition Security, \\ The Nelson Mandela African Institution of Science and Technology, Arusha, Tanzania
}

Correspondence should be addressed to Daniel Nyoki; dnyoki@yahoo.com

Received 4 September 2017; Revised 5 December 2017; Accepted 24 January 2018; Published 1 March 2018

Academic Editor: Yuanhu Xuan

Copyright (C) 2018 Daniel Nyoki and Patrick A. Ndakidemi. This is an open access article distributed under the Creative Commons Attribution License, which permits unrestricted use, distribution, and reproduction in any medium, provided the original work is properly cited.

The field experiment was carried out in northern Tanzania to assess the effects of intercropping systems, Rhizobium inoculation, and fertilization with $\mathrm{P}$ and $\mathrm{K}$ on chemical properties of soybean rhizosphere soil. The experiment was laid out in split-split plot design with $2 \times 4 \times 7$ factorial arrangement replicated thrice. The main plots had two inoculation treatments and the subplots were comprised of four cropping systems which were sole maize, sole soybean, and two intercropping at different soybean spacing $(75 \times$ 20 and $75 \times 40 \mathrm{~cm})$. The fertilizer levels $(\mathrm{kg} / \mathrm{ha})$ control $(0 \mathrm{~kg} / \mathrm{ha}) ; 20 \mathrm{~K} ; 40 \mathrm{~K} ; 26 \mathrm{P} ; 52 \mathrm{P} ; 26 \mathrm{P}+20 \mathrm{~K}$; and $52 \mathrm{P}+40 \mathrm{~K}$ were assigned to sub-subplots. Statistical analysis was performed using ANOVA. Least Significant Difference was used to compare treatment means at $p=0.05$ significance level. The results indicated that rhizosphere soil chemical properties such as $\mathrm{pH}$, organic carbon $(\mathrm{OC})$, and macro- and micronutrients $(\mathrm{N}, \mathrm{P}, \mathrm{Ca}, \mathrm{Mg}$, and $\mathrm{Na}$ and $\mathrm{Fe}, \mathrm{Cu}, \mathrm{Mn}$, and $\mathrm{Zn}$, resp.) were significantly increased in the Rhizobium inoculated soybean over the control. The supply of $\mathrm{P}$ and $\mathrm{K}$ fertilizers significantly increased the rhizosphere content of macronutrients $(\mathrm{P}, \mathrm{K}, \mathrm{Ca}$, and $\mathrm{Mg}$ ) and also they altered the $\mathrm{pH}$ and $\mathrm{EC}$ of the rhizosphere soil relative to control.

\section{Introduction}

Plants require 17 nutrients to perform different plant functions related to growth, development, and reproduction. However, most soils in sub-Saharan Africa are depleted and are deficient in mineral elements to sustain crop production [1-3]. Each of these plant nutrients is needed in deferent amount by plants and they differ in their mobility and availability in the plants and soil. In agroecosystems where most farmers prefer to grow more than one crop in the same piece of land at the same time, there are maximum interactions between plant roots and soil [4]. The concentration of plant nutrients in the zone of soil-roots interactions (rhizosphere) is reported to be different from bulk soil [5]. Compared with the bulk soil, rhizosphere soil is said to have high concentration of mineral elements and soil microorganisms (both beneficial and harmful) [6,7]. Interactions between roots and soil during plant growth induce changes in the soil that make rhizosphere soil to differ from bulk soil $[8,9]$. These changes in the rhizosphere may be caused by root uptake of nutrients, microbial activity, and/or components of root exudates $[5,10]$. Plants release several low and high molecular weight organic compounds such as sugars, organic acids, amino acids, and phenolics into the rhizosphere $[5,11]$. The compounds that are released can lead to dissolution of primary minerals and precipitation or crystallization of secondary compounds and/or minerals and eventually transformation of mineral components in the rhizosphere [6]. 
Plant Growth Promoting Rhizobacteria (PGPR) also do concentrate in the rhizosphere soil and confer the plants with beneficial effects such as solubilization of mineral nutrients, fixation of nitrogen, and disease suppression resulting from plant pathogens [12-17]. Bambara and Ndakidemi [18] reported a significant increase in soil $\mathrm{pH}, \mathrm{Ca}$, and $\mathrm{Na}$ following Rhizobium inoculation on Phaseolus vulgaris. Crop diversity in the field increases concentration of microbes in the rhizosphere soil compared with the single species because of specificity of microbes to plant species. Intercropping cereal with legume crops such as cowpea, mungbean, soybean, and groundnuts can fix and accumulate nitrogen ranging from 80 to $350 \mathrm{~kg} \mathrm{ha}^{-1}$ per year [19], thereby improving soil fertility. Intercropping also can enhance nutrient mineralization because it improves the decomposition rates of soil organic matter $[20,21]$. Biological nitrogen fixation induces changes in the soil $\mathrm{pH}$ resulting in limited availability of some plant nutrients in the soil [22].

Currently, there is limited information about the effect of Rhizobium inoculation on the chemical composition in the rhizosphere of soybean intercropped with maize, supplemented with lower and higher rates of phosphorus (P) and potassium (K) fertilizers. Therefore, the current study was carried out to determine the effects of intercropping systems, Rhizobium inoculation, and fertilization with different levels of $\mathrm{P}$ and $\mathrm{K}$ singly or combined application on chemical properties of soybean rhizosphere soil after two consecutive cropping seasons.

\section{Material and Methods}

2.1. Experimental Design and Treatments. The field experiment was conducted in the same place for two consecutive years (2015 and 2016 cropping seasons). The treatments for year one were repeated in year two in the same spots. The experimental trials were set at Tanzania Coffee Research Institute (TaCRI) farm in northern Tanzania. The experiment followed a split-split plot design with factorial arrangement and replicated thrice. The plot measured $3 \times 3 \mathrm{~m}$. The main plots had two Rhizobia inoculation treatments, while the subplots were comprised of the following treatments: maize (sole crop) at a spacing of $75 \times 60 \mathrm{~cm}$; soybean (sole crop) at a spacing of $75 \times 40 \mathrm{~cm}$; maize/soybean (intercropping system) at a spacing of $75 \times 60 \mathrm{~cm}$ and $75 \times 20 \mathrm{~cm}$, maize, and soybean, respectively; and the last cropping system was maize/soybean (intercropping system) at a spacing of $75 \times 60 \mathrm{~cm}$ and 75 $\times 40 \mathrm{~cm}$, maize, and soybean, respectively. The sub-subplots were treated with the following fertilizer levels $\left(\mathrm{kg} \mathrm{ha}^{-1}\right)$ : control $\left(0 \mathrm{~kg} \mathrm{ha}^{-1}\right) ; 20 \mathrm{~K} ; 40 \mathrm{~K} ; 26 \mathrm{P} ; 52 \mathrm{P} ; 26 \mathrm{P}+20 \mathrm{~K} ; 52$ $\mathrm{P}+40 \mathrm{~K}$. The sources of these elements were Triple Super Phosphate (TSP for P) and Muriate of Potash (MOP) for $\mathrm{K}$. The BIOFIX legume inoculants (Bradyrhizobium japonicum) were obtained from MEA Company Nairobi-Kenya, sold under the license from the University of Nairobi. The inoculants were supplied with gum Arabic for sticking as many cells as possible into the seeds. Inoculation was done following manufacturers' instructions where thirty (30) gram of gum Arabic was added to $300 \mathrm{ml}$ of water and mixed to form a solution. $15 \mathrm{~kg}$ of soybean seeds was weighed and
$300 \mathrm{ml}$ of gum Arabic solution was added and mixed well. 50 gm of legume inoculants was added and mixed well so that all seeds are coated. The inoculated seeds were put under shade for 15 minutes to ensure the inoculants stick well on seeds and the seeds were then sown immediately in a wet moist soil. To avoid contamination of inoculation treatments, the uninoculated plots were sown first followed by inoculated plots.

2.2. Sample Collection. Rhizosphere soil used in this study was collected during the second year of the experimentation when the soybean was at $50 \%$ pod formation. The rhizosphere soils were sampled from five plants of middle rows for each plot excluding the border plants. This was achieved by careful excavation of soil from around each plant down to about $10-20 \mathrm{~cm}$ depending on root depth of the respective plant and removed with the plant and its roots intact inside the bulge of soil. The rhizosphere soil adhering to plant roots was shaken in the labeled bags, air dried in the laboratory, and sieved $(2 \mathrm{~mm})$ ready for determination of $\mathrm{pH}$, organic carbon, and analysis of nutrients. The samples collected from each plot for the two cropping season were pooled together and well mixed to form one sample per treatment.

\subsection{Determination of Plant-Available Nutrients in Rhizosphere} Soil. Total N was determined by the method of microKjeldahlas described by Bremner [23]. Phosphorus was determined by the molybdenum blue method [24]. Concentrations of elements such as $\mathrm{Ca}, \mathrm{Mg}, \mathrm{K}$, and $\mathrm{Na}$ were determined by method described in Hesse [25]. The trace elements such as $\mathrm{Cu}, \mathrm{Zn}, \mathrm{Fe}$, and $\mathrm{Mn}$ were extracted by diethylenetriaminepentaacetic acid (DTPA) [26] and determined by an atomic absorption spectrophotometer. The rhizosphere soil $\mathrm{pH}$ was analysed in $1: 2.5$ (soil : water) suspension, by the electrometric method [27], and electrical conductivity (EC), measured in a 1:5 (soil: water) suspension, using the electrometric method [27]. The organic carbon was determined by the Walkley and Black method [28].

2.4. Statistical Analyses. The collected data was analysed using statistical software called STATISTICA. The statistical analyses were performed using analyses of variance (ANOVA) in factorial arrangement. Fisher's least significant difference (LSD) was used to compare treatment means at $p=0.05$ level of significance [29].

\section{Results}

3.1. Effects of Cropping Systems on Rhizosphere Soil Chemical Properties. The results indicated that, except for sodium (Na), cropping systems had no significant effects on the chemical properties of the soybean rhizosphere soil. Only sodium was observed to be greater in the rhizosphere soil of soybean grown under maize intercropping systems compared with the rhizosphere soil of soybean pure stand (Table 1).

\subsection{Effects of Rhizobium Inoculation on Rhizosphere Soil} Chemical Properties. Rhizobium inoculation was observed to alter the most of the chemical properties of the rhizosphere soil of soybean compared with the rhizosphere soil collected 


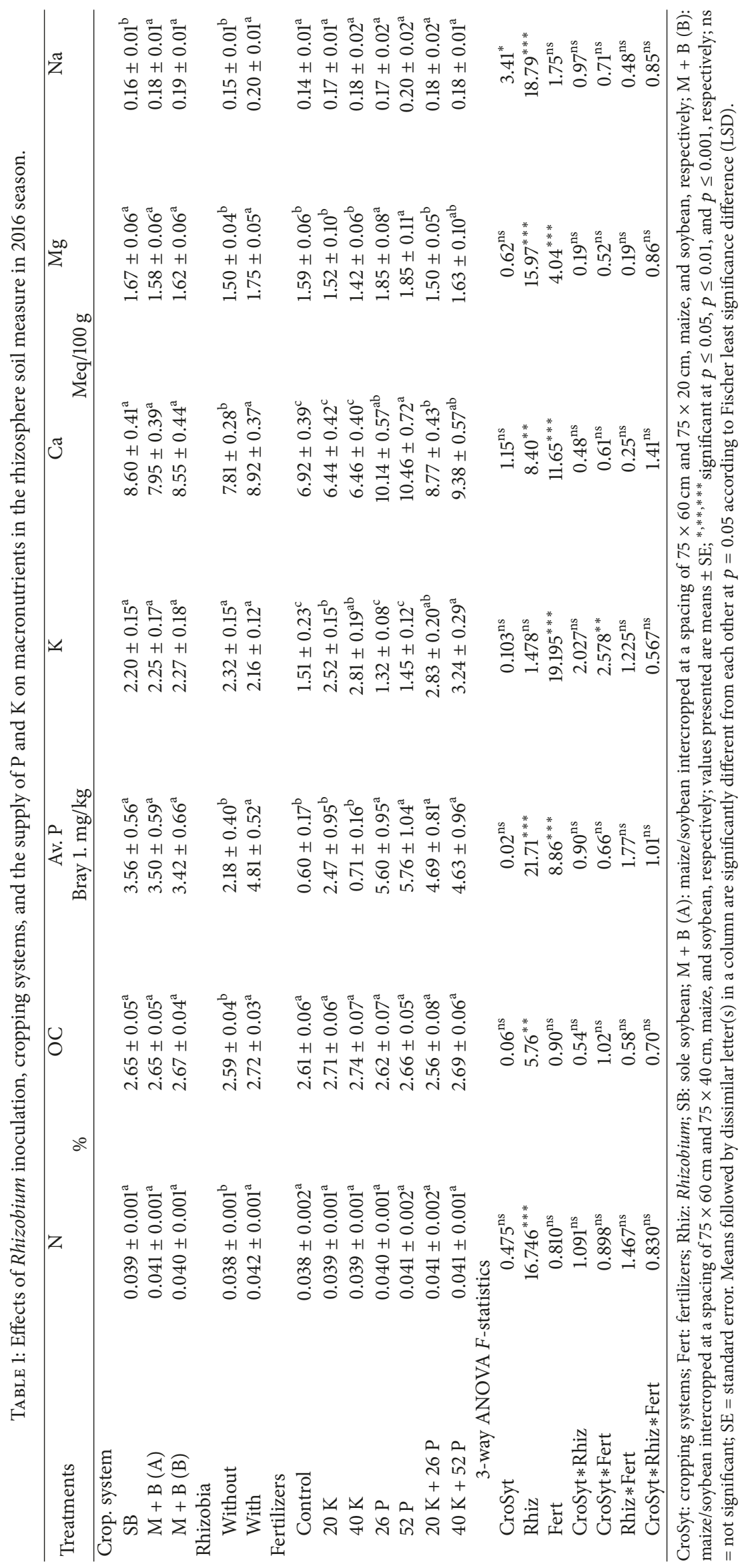


from uninoculated soybean. Rhizosphere soil chemical properties that were significantly increased in the inoculated soybean includes macro- and micronutrients $(\mathrm{N}, \mathrm{P}, \mathrm{Ca}, \mathrm{Mg}$, $\mathrm{Na}$, and $\mathrm{OC}$ and $\mathrm{pH}, \mathrm{Fe}, \mathrm{Cu}, \mathrm{Mn}, \mathrm{Zn}$, resp.). In this study, Rhizobium inoculation treatment did not significantly alter the concentration of EC and $\mathrm{K}$ in the rhizosphere soil (Tables 1 and 2). Specifically, Rhizobium inoculation increased the concentration of chemical $(\mathrm{N}, \mathrm{P}, \mathrm{Ca}, \mathrm{Mg}, \mathrm{Na}$, and $\mathrm{OC})$ in the soil by $10.5,120.6,14.2,16.7,33.3$, and $17.8 \%$ respectively. Similarly, the rhizosphere $\mathrm{pH}$ and micronutrients $(\mathrm{Fe}, \mathrm{Cu}$, $\mathrm{Mn}$ and $\mathrm{Zn}$ ) were, respectively, increased by 1.3, 10.6, 31.4, 41.7 , and $25 \%$ in Rhizobium inoculated soybean relative to uninoculated soybean.

\subsection{Effects of $P$ and $K$ Fertilization on Rhizosphere Soil} Chemical Properties. Fertilization of crop (soybean) with P and $\mathrm{K}$ did not significantly change the concentration nitrogen, sodium, and the organic matter content of rhizosphere soil. However, application of these fertilizers significantly increased the rhizosphere content of macronutrients such as $\mathrm{P}, \mathrm{K}, \mathrm{Ca}$, and $\mathrm{Mg}$ (Table 1). $\mathrm{P}$ and $\mathrm{K}$ fertilization also altered the $\mathrm{pH}$ and $\mathrm{EC}$ of the rhizosphere soil relative to control (Table 2).

3.4. Interactions. The current study showed that there were significant interactions between cropping systems and fertilizers on rhizosphere soil $\mathrm{K}$ content and between cropping systems and Rhizobium inoculation on rhizosphere soil $\mathrm{pH}$. Fertilization with two levels of $\mathrm{K}$ significantly increased the rhizosphere K over the plots fertilized with P and the control. The plots that were fertilized with $\mathrm{P}$ had statistically the same rhizosphere $\mathrm{K}$ with the control (Figure 1). The highest rhizosphere $\mathrm{K}$ level was recorded in soybean intercropped with maize at wider spacing and fertilized with doubled combined fertilizers, while the lowest level of rhizosphere $\mathrm{K}$ was recorded in the control plots (Figure 1). The rhizosphere soil $\mathrm{pH}$ was significantly higher in Rhizobium inoculated plots over uninoculated one throughout the cropping systems. The highest $\mathrm{pH}$ value was recorded in Rhizobium inoculated pure stand while the lowest was recorded in uninoculated pure stand soybean (Figure 2).

\section{Discussion}

The findings of this study showed that Rhizobium inoculation altered the chemical composition of rhizospheres soil relative to uninoculated treatments. Rhizobium inoculation reduced the soil acidity by increasing the rhizosphere soil $\mathrm{pH}$ relative to uninoculated treatments. Similar findings were reported by Bambara and Ndakidemi [18] who found that Rhizobium inoculation significantly increased the soil $\mathrm{pH}$ in the rhizosphere of $P$. vulgaris. Furthermore, Rhizobium inoculation altered the chemical properties of rhizosphere whereby most of the mineral elements were increased in rhizosphere soils of inoculated soybean over the control. There are several possible explanations for increased concentration of macroand micronutrients in the rhizosphere soils of inoculated soybean. Firstly, it is due to increased soil $\mathrm{pH}$ which favoured the availability of most plant nutrients [30,31]. Increased availability of nutrients in the rhizosphere soil provides

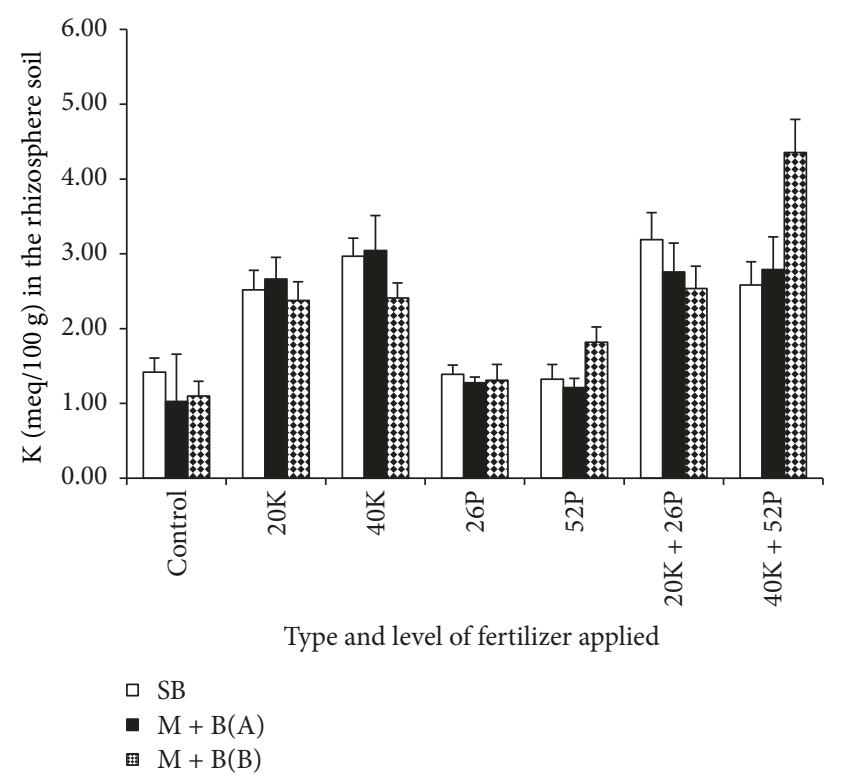

FIGURE 1: Interactive effect of cropping systems and fertilizers on rhizosphere soil $K$ content. SB: sole soybean; $M+B(A)$ : maize/soybean intercropped at a spacing of $75 \times 60 \mathrm{~cm}$ and $75 \times$ $20 \mathrm{~cm}$, maize, and soybean, respectively; $\mathrm{M}+\mathrm{B}(\mathrm{B})$ : maize/soybean intercropped at a spacing of $75 \times 60 \mathrm{~cm}$ and $75 \times 40 \mathrm{~cm}$, maize, and soybean, respectively.

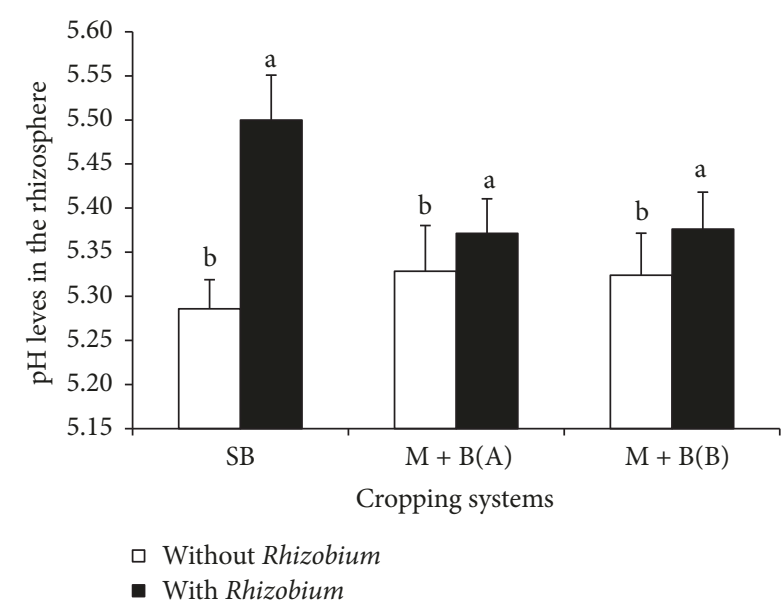

FIGURE 2: Interactive effect of cropping systems and Rhizobium inoculation on rhizosphere soil $\mathrm{pH}$. SB: sole soybean; $\mathrm{M}+\mathrm{B}(\mathrm{A})$ : maize/soybean intercropped at a spacing of $75 \times 60 \mathrm{~cm}$ and $75 \times$ $20 \mathrm{~cm}$, maize, and soybean, respectively; $\mathrm{M}+\mathrm{B}(\mathrm{B})$ : maize/soybean intercropped at a spacing of $75 \times 60 \mathrm{~cm}$ and $75 \times 40 \mathrm{~cm}$, maize, and soybean, respectively.

normal growth of plants and eventually increased yield. Normally, if there is low soil $\mathrm{pH}$, the soil is acidic which results in poor plant growth and development as most of plant nutrients become unavailable for plants. Secondly, mineralization activities of rhizospheric microorganisms tend to solubilize mineral elements such as $\mathrm{P}$ and make it available in the soil [32]. Thirdly, Rhizobium produces Fe career compound called siderophores which tends to increase the Fe content in 


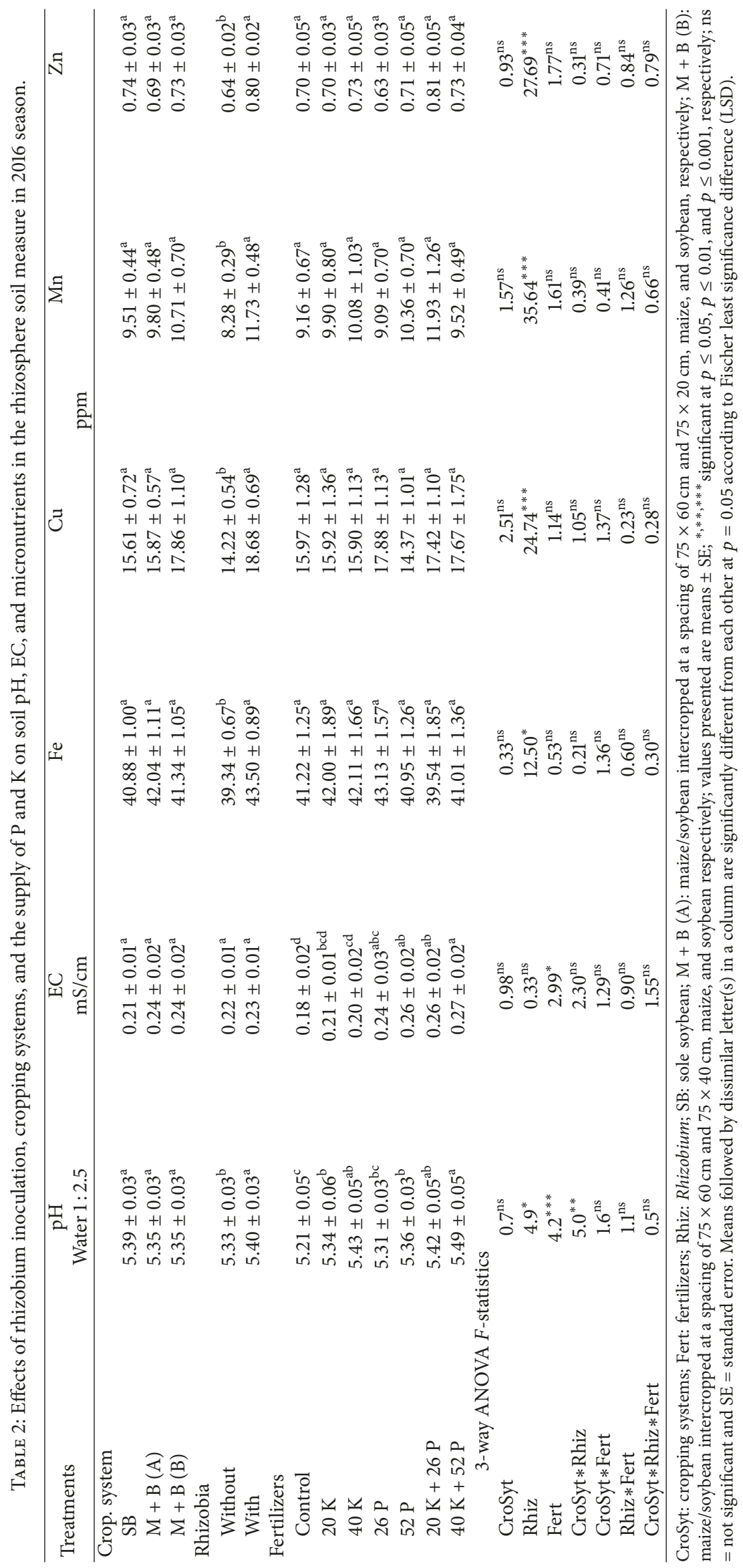


the rhizosphere soil $[33,34]$. Fourthly, the decaying cells of microorganisms release nutrients and make them available in the rhizosphere soil [35]. Fifthly, mineral elements can be excreted in the rhizosphere soil as exudates from plant roots [36]. Sixth, the decayed plant biomasses lead to increased nutrients in the soil. The increased biomass due to inoculation means that, as it decays, it will release larger quantities of nutrients into the soil that it has accumulated [37].

All these processes are taking place in the soil and in one way or another may have attributed to the increased chemical properties of rhizosphere soil of Rhizobium inoculated soybean. The current study also showed that organic carbon significantly increased in the rhizosphere soil of Rhizobium inoculated soybean over the control. The increase in organic carbon content might be attributed to better root growth and deposition of organic materials in first cropping season since these data were taken in the second cropping season. Similar findings were reported by Sharma et al. [38] and Sharma and Verma [39]. However, our findings on organic carbon content in the rhizosphere differed with that of Yusif et al. [40] who found that Rhizobium inoculation decreased the soil $\mathrm{pH}$ and the organic carbon. They urged that decrease of organic carbon may have been attributed by increased microorganisms which hasted decomposition of organic carbon in the rhizosphere.

The results also showed that $\mathrm{P}$ and $\mathrm{K}$ fertilization increased the concentration of $\mathrm{P}, \mathrm{K}, \mathrm{Ca}$, and $\mathrm{Mg}$ in the rhizosphere over the control (Table 1). Increased concentration of $\mathrm{Ca}$ and $\mathrm{Mg}$ in the rhizosphere soil may have been attributed by synergistic effect of $\mathrm{P}$ and $\mathrm{K}$ which made these nutrients to concentrate more in the rhizosphere soil. The significant increase of $\mathrm{P}$ and $\mathrm{K}$ in the rhizosphere soil has been attributed by $\mathrm{P}$ and $\mathrm{K}$ fertilization which increased the availability of these nutrients. Furthermore, root exudates may have contributed to the increased macronutrients in the plots treated with $\mathrm{P}$ and $\mathrm{K}$. It was also noted that the rhizosphere soil $\mathrm{pH}$ and electrical conductivity (EC) were significantly higher in $\mathrm{P}$ and $\mathrm{K}$ fertilized plots relative to control. Soil electrical conductivity (EC) provides the measurement of the amount of salts in soil (salinity of soil) [41, 42]. EC affects crop yields, crop suitability, plant nutrient availability, and activity of soil microorganisms which influence key soil processes. However, EC does not provide a direct measurement of specific ions or salt compounds. Researchers have correlated it to concentrations of ions such as $\mathrm{N}, \mathrm{P}, \mathrm{K}, \mathrm{Ca}, \mathrm{Mg}, \mathrm{Na}, \mathrm{Mn}$, $\mathrm{Zn}$, and $\mathrm{Cu}$ [42-44]. Their finding are in line with our results which showed the increased EC in plots treated with $\mathrm{P}$ and $\mathrm{K}$ fertilizers compared with the control.

There were significant interactions between cropping systems and fertilizers on rhizosphere soil $\mathrm{K}$ content and between cropping systems and Rhizobium inoculation on rhizosphere soil $\mathrm{pH}$. Potassium fertilization significantly interacted with cropping system and contributed to the available $\mathrm{K}$ in the rhizosphere soil. The highest $\mathrm{K}$ level was recorded in rhizosphere soil of soybean intercropped with maize at wider spacing and fertilized with doubled combined fertilizers, while the lowest level of rhizosphere $\mathrm{K}$ was recorded in the control plots. The rhizosphere soil $\mathrm{pH}$ was significantly higher in Rhizobium inoculated plots over uninoculated one throughout the cropping systems. The highest $\mathrm{pH}$ value was recorded in Rhizobium inoculated pure stand while the lowest was recorded in uninoculated pure stand soybean suggesting that microorganisms such as Rhizobium can help to reduce soil acidity.

\section{Conclusion}

Rhizobium inoculation altered most of the chemical properties of the rhizosphere soil of soybean in this study. The rhizosphere soil chemical properties such as $\mathrm{pH}, \mathrm{OC}, \mathrm{EC}$, and macro- and micronutrients $(\mathrm{N}, \mathrm{P}, \mathrm{Ca}, \mathrm{Mg}$, and $\mathrm{Na}$, and $\mathrm{Fe}, \mathrm{Cu}, \mathrm{Mn}$, and $\mathrm{Zn}$, resp.) were significantly increased in the Rhizobium inoculated soybean over the control. These results strongly support the use of microorganism to improve soil chemical properties for improved plant growth, development, and production. The supply of $\mathrm{P}$ and $\mathrm{K}$ fertilizers significantly increased the rhizosphere content of macronutrients such as $(\mathrm{P}, \mathrm{K}, \mathrm{Ca}$, and $\mathrm{Mg}$ ) and also they altered the $\mathrm{pH}$ and $\mathrm{EC}$ of the rhizosphere soil relative to control.

\section{Conflicts of Interest}

The authors declare that there are no conflicts of interest regarding the publication of this paper.

\section{Acknowledgments}

The authors are thankful to the Government of Tanzania through Nelson Mandela African Institution of Science and Technology for funding this study.

\section{References}

[1] P. A. Sanchez, "Soil fertility and hunger in Africa," Science, vol. 295, no. 5562, pp. 2019-2020, 2002.

[2] P. A. Sanchez and M. S. Swaminathan, "Hunger in Africa: The link between unhealthy people and unhealthy soils," The Lancet, vol. 365, no. 9457, pp. 442-444, 2005.

[3] N. Sanginga and P. L. Woomer, "Integrated Soil Fertility Management," in Proceedings of the in Africa: Principles, Practices and Developmental Process, p. 263, 2009.

[4] P. A. Ndakidemi, "Manipulating legume/cereal mixtures to optimize the above and below ground interactions in the traditional African cropping systems," African Journal of Biotechnology, vol. 5, no. 25, pp. 2526-2533, 2006.

[5] P. Hinsinger, G. R. Gobran, P. J. Gregory, and W. W. Wenzel, "Rhizosphere geometry and heterogeneity arising from rootmediated physical and chemical processes," New Phytologist, vol. 168, no. 2, pp. 293-303, 2005.

[6] J. Cabala, E. Teper, L. Teper, E. Małkowski, and A. Rostański, "Mineral composition in rhizosphere of plants grown in the vicinity of a $\mathrm{Zn}-\mathrm{Pb}$ ore flotation tailings pond. Preliminary study," Acta Biologica Cracoviensia Series Botanica, vol. 46, pp. 65-73, 2004.

[7] W. Cheng and A. Gershenson, "Carbon Fluxes in the rhizosphere. The Rhizosphere," An ecological perspective, pp. 29-54, 2007.

[8] X. Wang and D. Zabowski, "Nutrient composition of Douglasfir rhizosphere and bulk soil solutions," Plant and Soil, vol. 200, no. 1, pp. 13-20, 1998. 
[9] J. H. J. R. Makoi, S. B. M. Chimphango, and F. D. Dakora, "Changes in rhizosphere concentration of mineral elements as affected by differences," American Journal of Experimental Agriculture, vol. 4, no. 2, pp. 193-214, 2014.

[10] X.-F. Huang, J. M. Chaparro, K. F. Reardon, R. Zhang, Q. Shen, and J. M. Vivanco, "Rhizosphere interactions: Root exudates, microbes, and microbial communitiesl," Botany, vol. 92, no. 4, pp. 267-275, 2014.

[11] H. Marschner and V. Römheld, "Root-induced changes in the availability of micronutrients in the rhizosphere," in Plant Roots, The Hidden Half, Y. Waisel, A. Eshel, and U. Kafkafi, Eds., pp. 557-579, Marcel Dekker, Inc, New York, NY, USA, 1996.

[12] A. Gupta, M. Gopal, and K. V. B. R. Tilak, "Mechanism of plant growth promotion by rhizobacteria," Indian Journal of Experimental Biology (IJEB), vol. 38, no. 9, pp. 856-862, 2000.

[13] D. M. Weller, J. M. Raaijmakers, B. B. McSpadden Gardener, and L. S. Thomashow, "Microbial populations responsible for specific soil suppressiveness to plant pathogens," Annual Review of Phytopathology, vol. 40, pp. 309-348, 2002.

[14] J. W. Kloepper, C. Ryu, and S. Zhang, "Induced systemic resistance and promotion of plant growth by Bacillus spp.," Journal of Phytopathology, vol. 94, no. 11, pp. 1259-1266, 2004.

[15] J. Yang, J. W. Kloepper, and C.-M. Ryu, "Rhizosphere bacteria help plants tolerate abiotic stress," Trends in Plant Science, vol. 14, no. 1, pp. 1-4, 2009.

[16] R. Mendes, M. Kruijt, I. De Bruijn et al., "Deciphering the rhizosphere microbiome for disease-suppressive bacteria," Science, vol. 332, no. 6033, pp. 1097-1100, 2011.

[17] M. I. Tahir, M. Inam-ul-Haq, M. Ashfaq, N. A. Abbasi, H. Butt, and H. Ghazal, "Screening of effective antagonists from potato rhizosphere against bacterial wilt pathogen," International Journal of Biosciences, vol. 8, no. 2, pp. 228-240, 2016.

[18] S. Bambara and P. A. Ndakidemi, "Changes in selected soil chemical properties in the rhizosphere of phaseolus vulgaris L. supplied with rhizobium inoculants, molybdenum and lime," Scientific Research and Essays, vol. 5, no. 7, pp. 679-684, 2010.

[19] M. B. Peoples and E. T. Craswell, "Biological nitrogen fixation: Investments, expectations and actual contributions to agriculture," Plant and Soil, vol. 141, no. 1-2, pp. 13-39, 1992.

[20] E. Blagodatskaya and Y. Kuzyakov, "Mechanisms of real and apparent priming effects and their dependence on soil microbial biomass and community structure: Critical review," Biology and Fertility of Soils, vol. 45, no. 2, pp. 115-131, 2008.

[21] H. R. Mobasser, M. R. Vazirimehr, and K. Rigi, "Effect of intercropping on resources use, weed management and forage quality," International Journal of Plant, Animal and Environmental Sciences, vol. 4, no. 2, pp. 706-713, 2014.

[22] N. S. Bolan, M. J. Hedley, and R. E. White, "Processes of soil acidification during nitrogen cycling with emphasis on legume based pastures," Plant and Soil, vol. 134, no. 1, pp. 53-63, 1991.

[23] J. M. Bremner, "Total Nitrogen," in Methods of Soil Analysis, C. A. Black, Ed., pp. 1149-1178, American Society of Agronomy, Madison, Wis, USA, 1965.

[24] J. Murphy and J. P. Riley, "A modified single solution method for the determination of phosphate in natural waters," Analytica Chimica Acta, vol. 27, pp. 31-36, 1962.

[25] P. R. Hesse, A Textbook of Soil Chemical Analysis, John Murray, London, UK, 1971.

[26] W. L. Lindsay and W. A. Norvell, "Development of a DTPA soil test for zinc, iron, manganese, and copper," Soil Science Society of America Journal, vol. 42, pp. 421-428, 1978.
[27] H. D. Chapman, "Cation-Exchange Capacity," in Methods of Soil Analysis, Part 2, C. A. Black, Ed., American Society of Agronomy, Soil Science Society of America, Madison, Wis, USA, 1965.

[28] A. Walkley and I. Black, "An examination of the Degtjareff method for determining soil organic matter, and a proposed modification of the organic acid titration method," Soil Science, vol. 37, no. 1, pp. 29-38, 1934.

[29] R. G. D. Steel and J. H. Torrie, Principles and Procedures of Statistics: A Biometrical Approach, McGraw-Hill Kogakusha, New York, NY, USA, 2nd edition, 1980.

[30] M. Bagayoko, S. Alvey, G. Neumann, and A. Buerkert, "Rootinduced increases in soil $\mathrm{pH}$ and nutrient availability to fieldgrown cereals and legumes on acid sandy soils of SudanoSahelian West Africa," Plant and Soil, vol. 225, no. 1-2, pp. 117127, 2000.

[31] L. M. Condron, H. Tiessen, C. Trasar-Cepeda, J. O. Moir, and J. W. B. Stewart, "Effects of liming on organic matter decomposition and phosphorus extractability in an acid humic Ranker soil from northwest Spain," Biology and Fertility of Soils, vol. 15, no. 4, pp. 279-284, 1993.

[32] F. D. Dakora and D. A. Phillips, "Root exudates as mediators of mineral acquisition in low-nutrient environments," Plant and Soil, vol. 245, no. 1, pp. 35-47, 2002.

[33] Y. Wang, H. N. Brown, D. E. Crowley, and P. J. Szaniszlo, "Evidence for direct utilization of a siderophore, ferrioxamine B, in axenically grown cucumber," Plant, Cell \& Environment, vol. 16, no. 5, pp. 579-585, 1993.

[34] P. J. White and M. R. Broadley, "Biofortification of crops with seven mineral elements often lacking in human diets-iron, zinc, copper, calcium, magnesium, selenium and iodine," New Phytologist, vol. 182, no. 1, pp. 49-84, 2009.

[35] M. E. McCulley, "Niches for bacterial endophytes in crop plants: a plant biologists view," Australian Journal of Plant Physiology, vol. 28, pp. 983-990, 2001.

[36] N. Ae, J. Arihara, K. Okada, T. Yoshihara, and C. Johansen, "Phosphorus uptake by pigeon pea and its role in cropping systems of the Indian subcontinent," Science, vol. 248, no. 4954, pp. 477-480, 1990.

[37] D. J. Bagyaraj, C. J. Nethravathi, and K. S. Nitin, "Soil biodiversity and arthropods: Role in soil fertility," in Economic and ecological significance of arthropods in diversified ecosystems, pp. 17-51, Springer, Singapore, 2016.

[38] R. P. Sharma, N. Datt, and G. Chander, "Effect of vermicompost, farmyard manure and chemical fertilizers on yield, nutrient uptake and soil fertility in okra (Abelmoschus esculentus) Onion (Allium cepa) sequence in wet temperate zone of Himachal Pradesh," Journal of the Indian Society of Soil Science, vol. 57, no. 3, pp. 357-361, 2009.

[39] R. Sharma and M. L. Verma, "Effect of Rhizobium, farm yard manure and chemical fertilizers on sustainable production and profitability of rajmash (Phaseolus vulgaris 1.) and soil fertility in dry temperate region of North-Western Himalayas," Legume Research, vol. 34, no. 4, pp. 251-258, 2011.

[40] S. Yusif, I. Muhammad, N. Hayatu et al., "Effects of biochar and rhizobium inoculation on selected soil chemical properties, shoot nitrogen and phosphorus of groundnut plants (arachis hypogaea 1.) in sokoto state, nigeria," Journal of Advances in Biology \& Biotechnology, vol. 8, no. 2, pp. 1-6, 2016.

[41] I. Shainberg, J. D. Rhoades, and R. J. Prather, "Effect of exchangeable sodium percentage, cation exchange capacity, and 
soil solution concentration on soil electrical conductivity," Soil Science Society of America Journal, vol. 44, no. 3, p. 469, 1980.

[42] R. Grisso, W. G. W. Mark Alley, D. Holshouser, and W. Thomason, Precision Farming Tools: Soil Electrical Conductivity," Virginia Cooperative Extension, publication 442-508, pp. 1-6, 2009, https://www.pubs.ext.vt.edu/content/dam/pubs_ext_vt_ edu/442/442-508/442-508_pdf.pdf.

[43] R. W. Heiniger, R. G. McBride, and D. E. Clay, "Using soil electrical conductivity to improve nutrient management," Agronomy Journal, vol. 95, no. 3, pp. 508-519, 2003.

[44] N. Hamzehpour and S. M. A. Abasiyan, "Spatial prediction of soil phosphorous using soil electrical conductivity as secondary information," Journal of Biodiversity and Environmental Sciences, vol. 8, no. 3, pp. 88-95, 2016. 


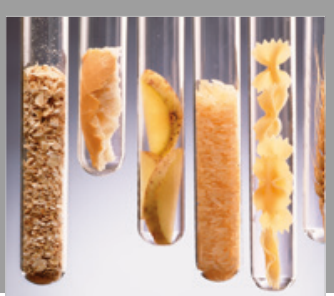

International Journal of Food Science

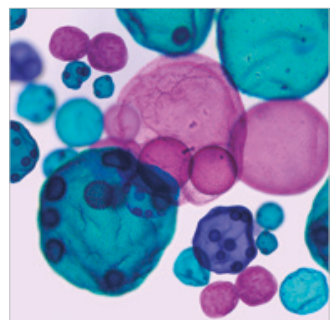

International Journal of Microbiology
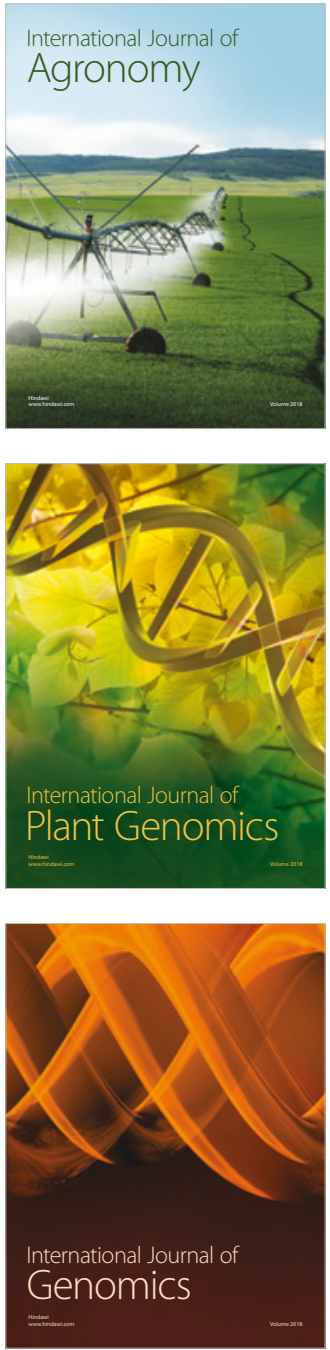

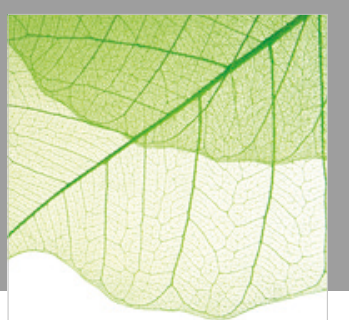

Journal of Botany
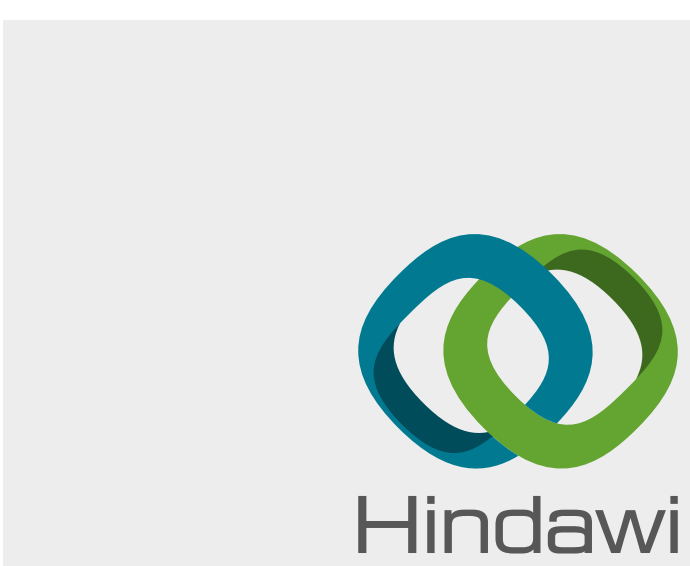

Submit your manuscripts at

www.hindawi.com
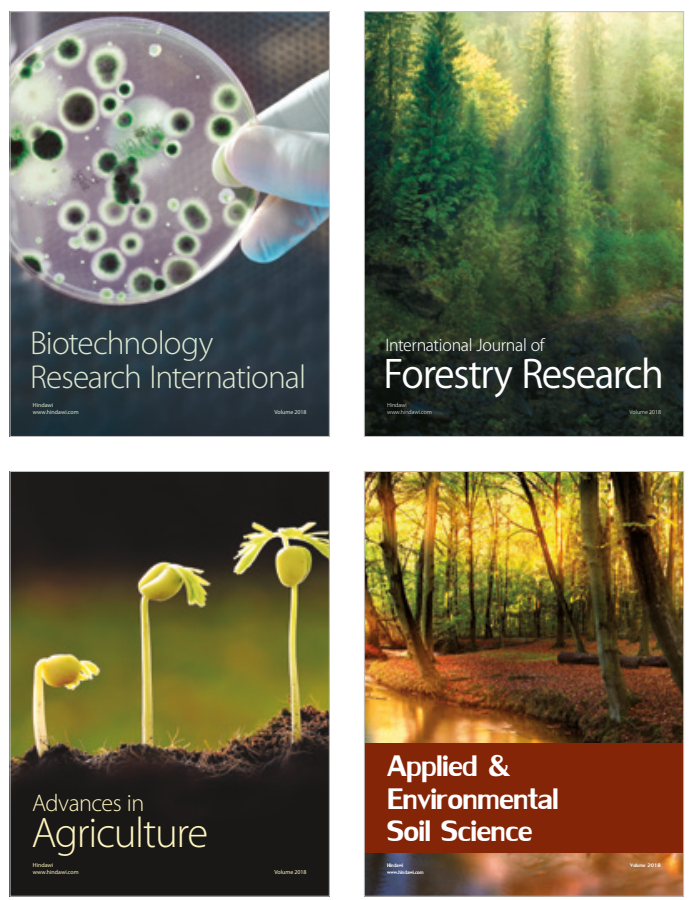

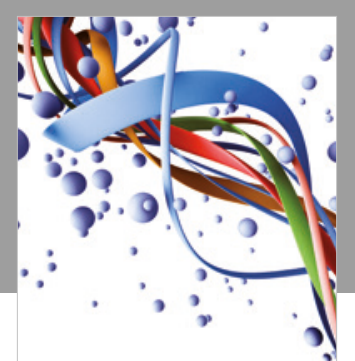

Scientifica

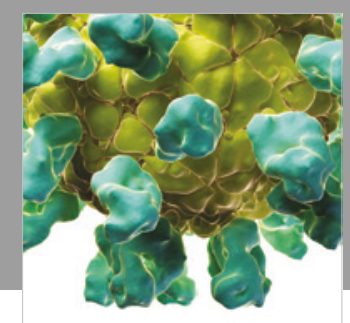

Veterinary Medicine International

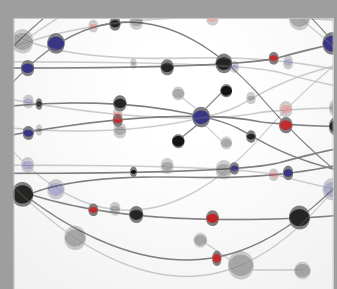

The Scientific World Journal
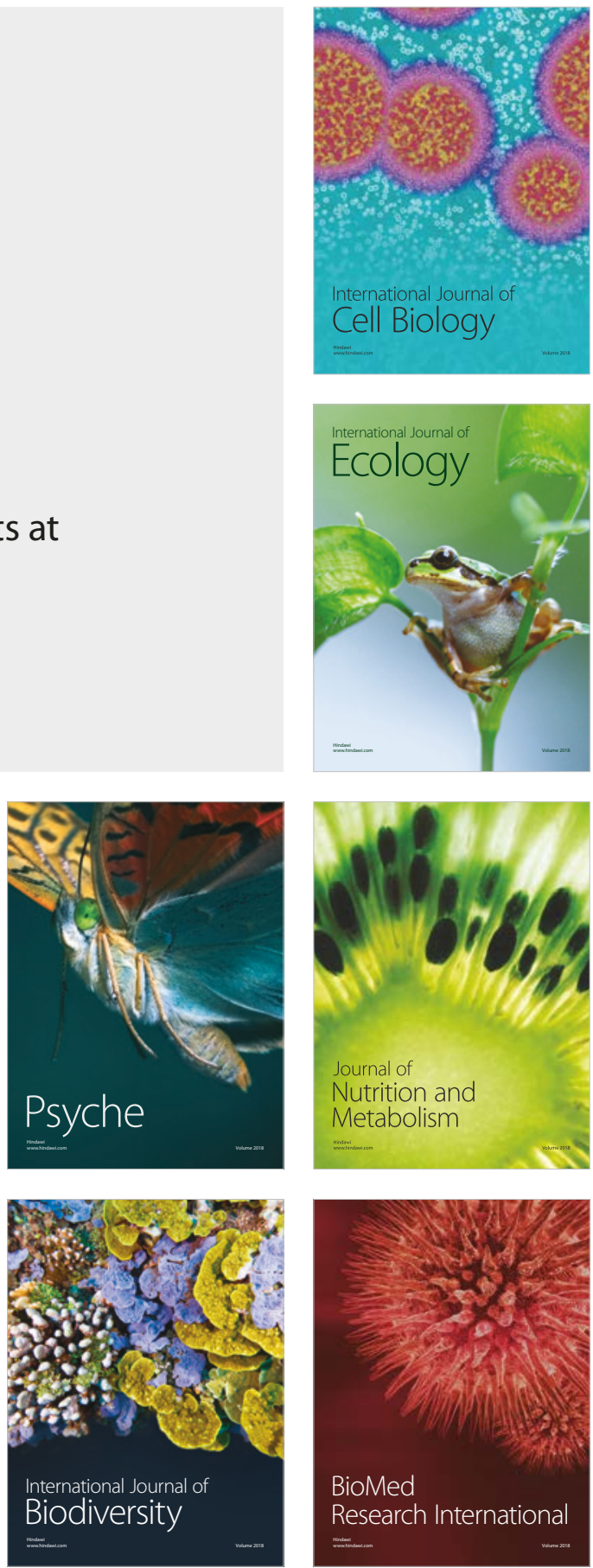